\title{
WATER SOLUBLE ANTIFUNGAL METABOLITES OF PEA (PISUM SATIVUM) LEAVES DETERMINE INFECTION BY ERYSIPHE PISI
}

\author{
Amar Bahadur*, B.K. Sarma, U.P. Singh \\ Department of Mycology and Plant Pathology, Institute of Agricultural Sciences Banaras Hindu University, Varanasi-221005, India
}

Received: February 20, 2009

Accepted: May 27, 2009

\begin{abstract}
Antifungal activity of water soluble exudates of pea leaves was assayed. Exudates of different nodal leaves were collected by dipping them in sterilized distilled water for different length of time and conidial germination of four non-pathogenic to pea fungi (Alternaria solani, Curvularia lunata, Helminthosporium penniseti and H. echinocloa) and one pea pathogenic to pea fungus (Erysiphe pisi) was observed in the collected exudates. The leaf exudates inhibited differently conidial germination and $A$. solani and $C$. lunata were found highly susceptible. Conidial germination on exudate-depleted pea leaves showed better germination of $E$. pisi than on non-depleted leaves. Bipolar germination was the highest on II and III nodal leaves dipped in distilled water for $18 \mathrm{~h}$ while after $24 \mathrm{~h}$ it was the highest on I nodal leaves following dipping in distilled water. Similarly, conidial germination of $E$. pisi was observed on different nodal leaves of pea of different age. It was very clear that young leaves did not support germination at all and on the same nodal leaves conidia germinated after the leaves became older. No germination was observed on less than 20-day-old leaves. Moreover, 30-day-old leaves were found to be highly susceptible as bipolar germination of E. pisi conidia was maximum on such leaves and did not increase with aging.
\end{abstract}

Key words: Centella asiatica, Andrographis paniculata, phenolic acids

\section{INTRODUCTION}

Pea (Pisum sativum) is an important pulse crop which is attacked by several pathogens causing severe losses to the growers annually. Among several fungal pathogens, powdery mildew of pea caused by E. pisi is one of the major destroyers of the crop. However, the infection is normally not seen when the plants are young and the first visible symptoms usually appear on the lowest leaves (I nodal leaves) on 15-16-day-old plants. The disease becomes severe on aged plants. Nothing is known so far as to the reason for preferential infection by E. pisi on older pea leaves. Tukey $(1966,1969)$ reviewed probable implications of metabolites leaching out from the above ground plant parts in relation to pathogen ingress. Several reports are available showing a wide spectrum of metabolically important biomolecules including amino acids, and their derivatives, organic acids, carbohydrates, nutrient ions and growth-regulating substances being leached out from leaves ( Yamada et al. 1964; Kozel and Tukey 1968; Mitchell 1968). Sadasivan et al. (1965) reported the presence of glutamine excess in the susceptible rice varieties which aided spore germination. Similarly, Saxena (1978) showed that rice leaf exudates of blast susceptible rice cultivars exuded asparagine, tyrosine, aspartic acid and glutamic acid whereas the resistant cultivars exuded only arginine. In a similar study conducted by Mohanty and Gangopadhyay (1981) it was noted that presence of increased total sugar along with some amino acids in rice leaf exudates markedly influenced spore germination in the leaf exudates of susceptible varieties at seedling stage. Keeping this in view the present investigation was carried to find out the effect of exudates of different nodal leaves of different plant age on conidial germination of E. pisi and some fungal pathogens of other hosts.

\section{MATERIALS AND METHODS}

\section{Plant and fungi}

Pea seeds (cv. Arkel) were sown in plastic pots of $20 \mathrm{~cm}$ dia (@10 seeds/pot) in a glasshouse and allowed to grow under regular conditions of moisture. The fungi (A. solani, C. lunata, H. echinocloa, H. penniseti and E. pisi) were isolated from their respective host plants, viz., potato (Solanum tuberosum), rice (Oryza sativa), Echinocloa sp., bajra (Pennisetum typhoides), pea (Pisum sativum) on potato dextrose agar (PDA) medium (pealed potato $200 \mathrm{~g}$, dextrose $20 \mathrm{~g}$, agar agar $20 \mathrm{~g}$, distilled water 1 l). The cultures were purified by single spore isolation technique for use in the experiments. Spores of E. pisi were taken directly from the infected pea plants.

\section{Collection of pea leaf exudates}

Different nodal (I the lowest II and III) leaves were collected from 30-day-old pea plants. Ten leaves from those nodes were dipped in $10 \mathrm{ml}$ of distilled water in $50 \mathrm{ml}$ beaker for different time intervals $(6,12,18$, and $24 \mathrm{~h})$. Separate leaves from the same nodes were used for different dipping 
variants. After a specified dipping period, the leaves were removed and the water containing leaf exudates was collected in culture tubes and stored at $4^{\circ} \mathrm{C}$ for further use.

\section{Antifungal activity of pea leaf exudates}

A drop of the exudate was placed on grease - free glass slides and fungal spores (200-300) from 10-day-old cultures of A. solani, C. lunata. H. echinocloa and H. penniset $i$ were picked up with a sterile inoculation needle and mixed in the solution. Conidia of E. pisi were directly lifted with an inoculation needle from heavily infected pea leaves. The slides were then placed in moist chambers prepared by placing two moist filter papers in the inner surfaces of a petri plate. Three replications were made for each solution of fungal spores. Spores mixed in distilled water without leaf exudates served as the control. The slides were incubated at $25 \pm 2^{\circ} \mathrm{C}$ for $24 \mathrm{~h}$ and then fixed with cotton blue in lactophenol. Germination was observed under a light microscope. All the experiments were conducted in triplicate.

\section{Conidial germination of $E$. pisi on pea leaves washed in distilled water}

30-day-old pea leaves from nodes (I, II and III) were collected after dipping in distilled water. Excess of moisture was removed by placing the leaves on filter paper. Different nodal leaves dipped for different time $(6,12,18$ and $24 \mathrm{~h}$ ) were then floated separately on $2 \%$ sucrose solution in petri plates. The floated leaves were inoculated with E. pisi conidia $\left(100-200 / \mathrm{mm}^{2}\right)$ by gently tapping heav- ily infected pea leaves over. These plates were incubated at $25 \pm 2{ }^{\circ} \mathrm{C}$ for 24 and $48 \mathrm{~h}$. Non-dipped in leaves served as control. The leaves were then handled according to Carver and Adaigbe method (1990) to remove the chlorophyll. After processing the leaves conidia were stained with cotton blue in lactophenol and conidial germination and mode of germination were observed under a light microscope. Data were recorded on at least 300 conidia in each treatment. The experiments were conducted in triplicate.

\section{Conidial germination of $E$. pisi on detached nodal leaves of different age}

Different nodal (I, II and III) leaves from pea plants raised in a glasshouse as mentioned earlier were excised from plants of different age (20, 25, 30, 35 and 40-day-old). The leaves were then floated separately on $2 \%$ sucrose solution followed by inoculation with E. pisi conidia as described earlier. The leaves were then processed after 24 and $48 \mathrm{~h}$ and germination and mode of germination of 300 conidia were recorded as described earlier. The experiments were conducted in triplicate and repeated twice.

\section{RESULTS}

\section{Fungal spore germination in pea leaf exudates}

Conidial germination of fungi under study was inhibited in exudates of pea leaves. Maximum inhibition was observed in A. solani dipped for 12 and $18 \mathrm{~h}$ in distilled water. Germination was drastically reduced in II and III nodal leaf exudates as compared to the I nodal leaf exu-

Table 1. Conidial germination of some fungi in exudates of different pea nodal leaves collected by dipping the leaves in sterilized distilled water for different time periods

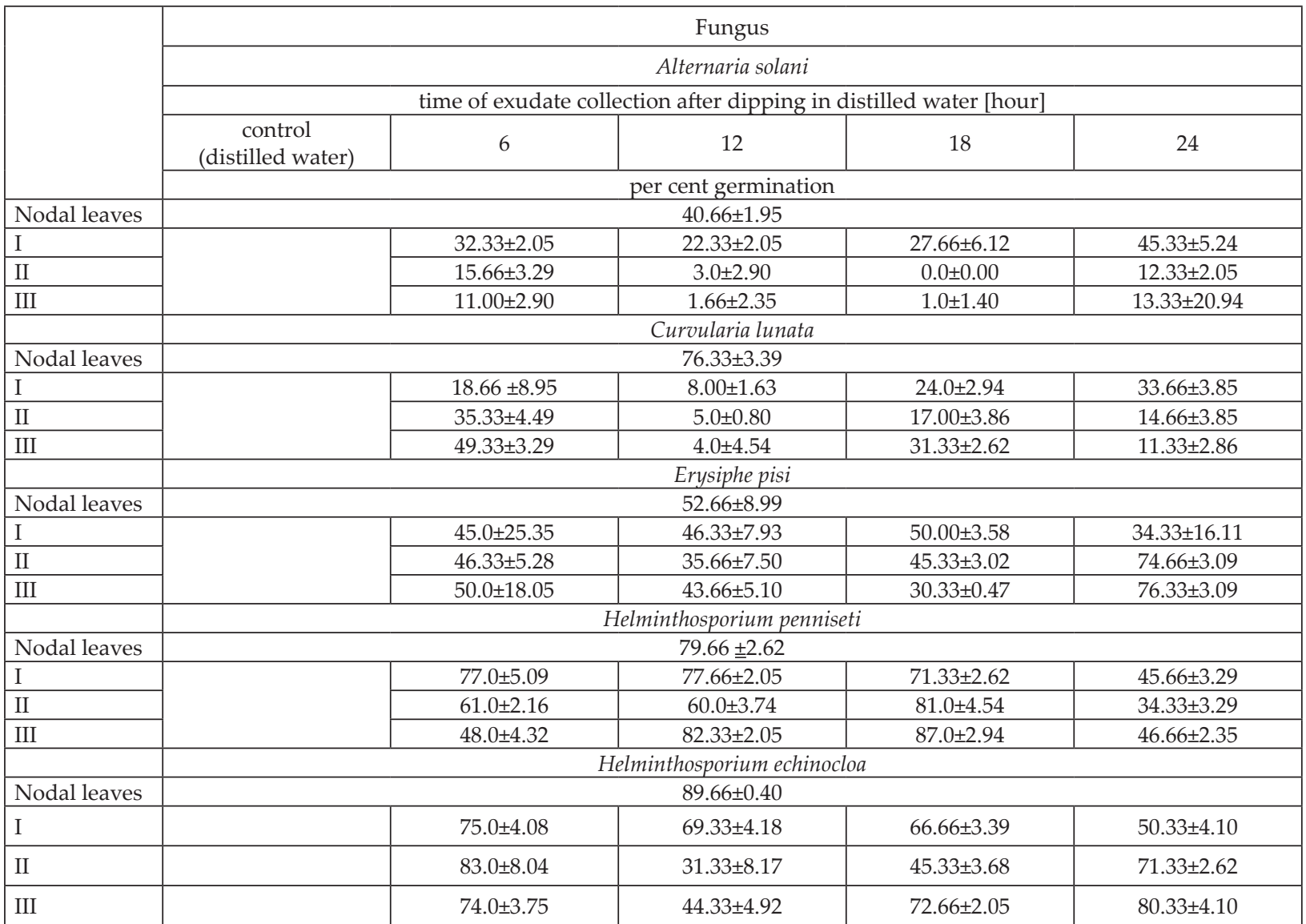


date. There was complete germination inhibition in exudates of II nodal leaves dipped for $18 \mathrm{~h}$. Similarly, there was a marked reduction in spore germination in C. lunata in exudate obtained after $12 \mathrm{~h}$ dipping. Although, there was reduction in spore germination in the exudate obtained after 6, 18 and $24 \mathrm{~h}$ dipping as compared to control, the germination percentage was higher than for the germination in $12 \mathrm{~h}$ dipped leaf exudate. Leaf exudate did not affect germination of both Helminthosporium species significantly. Although in most of cases the germination percentage of $H$. penniseti spores was lower than the control, there were few exceptions where germination percentage was only slightly higher than in the control. However, exudate obtained after dipping pea leaves for $24 \mathrm{~h}$ showed better inhibition as compared to exudate obtained from leaves dipped for lesser time periods. Exudate from the II nodal leaves gave the best result when the leaves were dipped for $24 \mathrm{~h}$. On the contrary, the germination percentage of H. echinocloa spores was less in all the solutions and the best inhibition was observed in $12 \mathrm{~h}$ dipped leaf exudate specifically in II nodal leaves. Germination of E. pisi conidia was also slightly inhibited by the leaf exudate obtained after dipping the leaves for different time intervals. The II and III nodal leaf exudates were more inhibitory as compared to I nodal leaves of 12 and $18 \mathrm{~h}$ dipping. However, the II and III nodal leaf exudates of $24 \mathrm{~h}$ yielded greater germination of E. pisi conidia as compared to control (Table 1).

\section{Conidial germination of $E$. pisi on exudate-depleted pea leaves}

Conidial germination of E. pisi was increased on exudate-depleted pea leaves at both 24 and $48 \mathrm{~h}$ of dipping. Leaves dipped for $24 \mathrm{~h}$ showed almost double germination of conidia compared to the control. All depleted nodal leaves supported better conidial germination as compared to non-exudate depleted control leaves (Table 2a). Interestingly, the mode of conidial germination differed on the exudated pea leaves. On all the nodal leaves bipolar germination increased in the exudate - depleted leaves as compared to control. This bipolar germination was more pronounced on II and III nodal leaves dipped in water for $18 \mathrm{~h}$ in contrast to $24 \mathrm{~h}$ dipping of I nodal leaves (Table $2 b$ ).

\section{Conidial germination of $E$. pisi on different nodal leaves of pea of different age}

Conidial germination of E. pisi was observed to be affected by the age of pea plants. Only older leaves were observed to support germination whereas younger leaves did not. Even after $48 \mathrm{~h}$ of incubation, younger leaves did not support germination whereas germination increased $48 \mathrm{~h}$ on old leaves compared to $24 \mathrm{~h}$ of incubation in most of the cases. However, the same nodal leaves supported conidial germination when the leaves grew old. An interesting observation was made in relation to mode of ger-

Table 2a. Conidial germination of E. pisi on different nodal leaves of pea (P. sativum) dipped in distilled water for different time periods

\begin{tabular}{|c|c|c|c|c|c|c|c|c|c|c|}
\hline \multirow{5}{*}{$\begin{array}{l}\text { Nodal } \\
\text { leaves }\end{array}$} & \multicolumn{10}{|c|}{ Period of observation [hour] } \\
\hline & \multicolumn{5}{|c|}{24} & \multicolumn{5}{|c|}{48} \\
\hline & \multicolumn{10}{|c|}{ dipping period [hours] } \\
\hline & $\begin{array}{c}\text { Control } \\
{[0]}\end{array}$ & 6 & 12 & 18 & 24 & $\begin{array}{c}\text { Control } \\
{[0]}\end{array}$ & 6 & 12 & 18 & 24 \\
\hline & \multicolumn{10}{|c|}{ per cent germination [uni- and bipolar] } \\
\hline I & $\begin{array}{r}33.33 \\
\pm 4.64 \\
\end{array}$ & $\begin{array}{r}31.00 \\
\pm 2.94 \\
\end{array}$ & $\begin{array}{l}59.66 \\
\pm 1.11\end{array}$ & $\begin{array}{l}72.33 \\
\pm 4.78 \\
\end{array}$ & $\begin{array}{r}75.33 \\
\pm 4.49 \\
\end{array}$ & $\begin{array}{l}42.66 \\
\pm 8.25\end{array}$ & $\begin{array}{r}24.66 \\
\pm 7.76 \\
\end{array}$ & $\begin{array}{c}59.33 \\
\pm 13.69 \\
\end{array}$ & $\begin{array}{l}67.66 \\
\pm 0.73\end{array}$ & $\begin{array}{l}90.66 \\
\pm 4.18\end{array}$ \\
\hline II & $\begin{array}{l}33.66 \\
\pm 2.40\end{array}$ & $\begin{array}{r}31.66 \\
\pm 3.68\end{array}$ & $\begin{array}{r}48.00 \\
\pm 6.16 \\
\end{array}$ & $\begin{array}{l}87.00 \\
\pm 6.16 \\
\end{array}$ & $\begin{array}{r}77.00 \\
\pm 6.68 \\
\end{array}$ & $\begin{array}{c}34.33 \\
\pm 11.81 \\
\end{array}$ & $\begin{array}{r}38.66 \\
\pm 6.79 \\
\end{array}$ & $\begin{array}{r}34.33 \\
\pm 6.64 \\
\end{array}$ & $\begin{array}{r}75.66 \\
\pm 4.78 \\
\end{array}$ & $\begin{array}{l}89.66 \\
\pm 2.05 \\
\end{array}$ \\
\hline II & $\begin{array}{l}39.66 \\
\pm 1.24\end{array}$ & $\begin{array}{l}28.66 \\
\pm 4.92\end{array}$ & $\begin{array}{c}68.33 \\
\pm 11.32\end{array}$ & $\begin{array}{c}71.5 \\
\pm 9.30\end{array}$ & $\begin{array}{l}80.00 \\
\pm 7.25\end{array}$ & $\begin{array}{l}44.66 \\
\pm 6.01\end{array}$ & $\begin{array}{l}31.00 \\
\pm 4.32\end{array}$ & $\begin{array}{l}63.00 \\
\pm 4.54\end{array}$ & $\begin{array}{r}91.33 \\
\pm 0.62\end{array}$ & $\begin{array}{r}74.00 \\
\pm 3.26\end{array}$ \\
\hline
\end{tabular}

Table 2b. Per cent of unipolar and bipolar conidial germination of E. pisi on different nodal leaves of pea (P. sativum) dipped in distilled water for different time periods

\begin{tabular}{|c|c|c|c|c|c|c|c|c|c|c|c|c|}
\hline \multirow{5}{*}{$\begin{array}{l}\text { Time of } \\
\text { dipping } \\
\text { leaves }\end{array}$} & \multicolumn{12}{|c|}{ Time of observation [hours] } \\
\hline & \multicolumn{6}{|c|}{$24 \mathrm{~h}$} & \multicolumn{6}{|c|}{$48 \mathrm{~h}$} \\
\hline & \multicolumn{6}{|c|}{ nodal leaves } & \multicolumn{6}{|c|}{ nodal leaves } \\
\hline & \multicolumn{2}{|c|}{ I } & \multicolumn{2}{|c|}{ II } & \multicolumn{2}{|c|}{ III } & \multicolumn{2}{|c|}{ I } & \multicolumn{2}{|c|}{ II } & \multicolumn{2}{|c|}{ III } \\
\hline & $\mathrm{U}$ & B & $\mathrm{U}$ & B & $\mathrm{U}$ & B & $\mathrm{U}$ & B & $\mathrm{U}$ & B & $\mathrm{U}$ & B \\
\hline Control & 29.00 & 4.33 & 28.06 & 5.60 & 36.00 & 3.66 & 26.66 & 16.00 & 19.67 & 14.66 & 33.00 & 11.66 \\
\hline $6 \mathrm{~h}$ & 31.00 & 0.00 & 28.66 & 3.00 & 24.34 & 4.32 & 14.66 & 10.00 & 30.66 & 8.00 & 16.00 & 15.00 \\
\hline $12 \mathrm{~h}$ & 59.66 & 0.00 & 48.00 & 0.00 & 68.00 & 0.00 & 59.33 & 0.00 & 34.33 & 0.00 & 63.00 & 0.00 \\
\hline $18 \mathrm{~h}$ & 72.33 & 0.00 & 39.40 & 47.60 & 37.76 & 36.90 & 67.66 & 0.00 & 51.66 & 24.00 & 33.07 & 58.26 \\
\hline $24 \mathrm{~h}$ & 47.00 & 28.33 & 77.00 & 0.00 & 80.00 & 0.00 & 39.76 & 60.90 & 89.66 & 0.00 & 42.80 & 31.20 \\
\hline
\end{tabular}

U - Unipolar, B - Bipolar 
Table 3. Conidial germination of E. pisi on different nodal leaves of different age

\begin{tabular}{|c|c|c|c|c|c|c|c|c|c|c|}
\hline \multirow{5}{*}{$\begin{array}{l}\text { Nodal } \\
\text { leaves }\end{array}$} & \multicolumn{10}{|c|}{ Time of observation [hours] } \\
\hline & \multicolumn{5}{|c|}{24} & \multicolumn{5}{|c|}{48} \\
\hline & \multicolumn{10}{|c|}{ age of leaf [days] } \\
\hline & 20 & 25 & 30 & 35 & 40 & 20 & 25 & 30 & 35 & 40 \\
\hline & \multicolumn{10}{|c|}{ per cent germination [uni- and bipolar] } \\
\hline I & $\begin{array}{l}51.00 \\
\pm 6.23\end{array}$ & $\begin{array}{l}54.66 \\
\pm 0.24\end{array}$ & $\begin{array}{l}39.00 \\
\pm 2.94\end{array}$ & $\begin{array}{l}50.33 \\
\pm 2.05\end{array}$ & $\begin{array}{l}53.66 \\
\pm 5.79\end{array}$ & $\begin{array}{l}72.66 \\
\pm 3.68\end{array}$ & $\begin{array}{l}55.33 \\
\pm 2.05\end{array}$ & $\begin{array}{l}65.66 \\
\pm 4.18\end{array}$ & $\begin{array}{l}70.33 \\
\pm 5.31\end{array}$ & $\begin{array}{l}35.66 \\
\pm 4.18\end{array}$ \\
\hline II & 0.00 & $\begin{array}{l}52.00 \\
\pm 1.41\end{array}$ & $\begin{array}{l}36.00 \\
\pm 2.94\end{array}$ & $\begin{array}{l}55.66 \\
\pm 8.99\end{array}$ & $\begin{array}{l}54.66 \\
\pm 2.05\end{array}$ & 0.00 & $\begin{array}{l}47.66 \\
\pm 2.05\end{array}$ & $\begin{array}{l}41.33 \\
\pm 2.62\end{array}$ & $\begin{array}{l}51.66 \\
\pm 6.23\end{array}$ & $\begin{array}{l}57.66 \\
\pm 2.05\end{array}$ \\
\hline III & 0.00 & 0.00 & $\begin{array}{l}47.66 \\
\pm 2.05\end{array}$ & $\begin{array}{l}63.33 \\
\pm 6.59\end{array}$ & $\begin{array}{l}57.66 \\
\pm 2.05\end{array}$ & 0.00 & 0.00 & $\begin{array}{l}44.66 \\
\pm 4.49\end{array}$ & $\begin{array}{l}96.33 \\
\pm 4.18\end{array}$ & $\begin{array}{l}43.66 \\
\pm 6.34\end{array}$ \\
\hline IV & 0.00 & 0.00 & 0.00 & $\begin{array}{r}63.33 \\
\pm 3.39\end{array}$ & $\begin{array}{l}54.66 \\
\pm 1.24\end{array}$ & 0.00 & 0.00 & 0.00 & $\begin{array}{l}60.00 \\
\pm 4.08\end{array}$ & $\begin{array}{l}48.66 \\
\pm 2.63\end{array}$ \\
\hline
\end{tabular}

mination. Maximum bipolar germination was observed in almost all nodal leaves of 30-day-old plants. The percentage of conidia germinated bipolarly on young leaves $(<30$-days-old) as well as older than $>30$-days leaves was less as compared to 30-day-old leaves (Table 3).

\section{DISCUSSION}

The leaf exudates of pea showed marked inhibition of conidial germination of E. pisi, A. solani, C. lunata, H. penniseti and H. echinocloa. From the present investigation it is very clear that pea leaves contain certain water soluble antifungal metabolites that inhibit spore germination of E. pisi and some pea non- pathogenic fungi. Among these A. solani was found to be most sensitive particularly to the II and III nodal leaf exudates which may be the result of presence of higher concentration of antifungal metabolites compared to the I nodal leaves. This observation was proved by E. pisi conidial germination test on normal pea leaves of different nodes which are of different age where the younger leaf exudates inhibited conidial germination completely in certain cases. The presence of antifungal metabolites was evident because when the similar leaves were dipped in distilled water for varied length of time and subsequently inoculated with E. pisi conidia, the exudate-depleted leaves showed higher conidial germination. The antifungal metabolites were not equally effective in inhibiting spore germination of all the test fungi because spore germination of Helminthosporium species was not inhibited to the same extent as in A. solani and C. lunata. Presence of various amino acids and sugars are reported by some worker (Saxena 1978; Mohanty and Gangopadhyay 1981). The preferential pathogenicity by pea pathogens may partially be due to their sensitivity towards the antifungal metabolites present in pea leaves especially at young stage. Flentje (1959) suggested that the susceptibility of young seedlings to $C$. solani may be associated with incomplete cuticular development, which allows diffusible metabolites to leak out and influence pathogenicity. According to Yamada et al. (1964) pectinaceous projections, cracks in the cuticle and lipid materials in the cuticle make movement of certain substances through the cuticle relatively easy, especially when the cuticle is wetted. This may be one of the most important reasons why powdery mildew infection usually appears first on the lower leaves of pea where cuticular development is believed to be complete, despite the equal exposure of leaves of all age to inoculum of powdery mildew (E. pisi). Moreover, more bipolar germination specially on the leaves of 30-day-old plants further confirms the most susceptible stage of pea plants to E. pisi. With this background information regarding the most susceptible stage of pea plants against E. pisi it is possible to formulate a suitable treatment schedule for better management of powdery mildew of pea. This appears to be a first scientific evidence regarding the most susceptible stage of pea leaves to E. pisi infection which is governed by the exudates leached out from the leaves at various stages of the plant growth.

\section{REFERENCES}

Carver T.L.W., Adaigbe M.E. 1990. Effect of oat genotype, leaf age and position and incubation humidity on germination and germling development by Erysiphe graminis f. sp. avenae. Mycol. Res. 94: 18-26.

Flentje N.T. 1959. Problems and progress. p. 76-87. In: “Plant Pathology" (C.S. Holton, ed.). University of Wisconsis Press, Madison.

Hilu H.M. 1965. Host-pathogen relationships of Puccinia sorghi in nearly isogenic resistant and susceptible seedling corn. Phytopathology 55: 563-569.

Kozel P.C., Tukey H.B.Jr. 1968. Loss or gibberellins by leaching from stems and foliage of Chrysanthemum morifolium 'Princess' Anne'. Am. J. Bot. 55: 1184-1189.

Leath K.T., Rowell J.B. 1966. Histological study of the resistance of Zea mays to Puccinia graminis. Phytopathology 56: 1305-1309.

Mitchell C.A. 1968. Detection of carbohydrates leached from above ground plant parts. M.S. Thesis, Cornell Univ., Ithaca, N.Y.

Mohanty C.R., Gangopadhyay S. 1981. Germination of Pyricularia oryzae spores in the leaf exudates of six rice varieties. Indian Phytopathol. 34: 296-299.

Saxena B.N. 1978. Rice leaf exudates in relation to blast disease. Indian Phytopathol. 31: 196-198.

Sadasivan T.S.S., Suryanarayan, Ramakrishna L. 1965. Effect of night temperature on pathogenicity in the rice blat disease. Proc. Symp. IRRI, 163 pp. 
Tukey H.B.Jr. 1966. Leaching metabolites from above-ground plant parts and its implication. Bull. Torrey Bot. Club. 93: 385-401.

Tukey H.B.Jr. 1969. Implications of allelopathy in agricultural plant science. Bot. Rev. 35: 1-16.

Yamada Y., Bukovac M.J., Wittwer S.H. 1964. Penetration of ions through isolated cuticles, Plant Physiol. 39: 28-32.

\section{POLISH SUMMARY}

\section{ROZPUSZCZALNE W WODZIE PRZECIWGRZYBOWE METABOLITY LIŚCI GROCHU (PISUM SATIVUM) WARUNKUJA PORAŻENIE PRZEZ ERYSIPHE PISI}

Testowano przeciwgrzybową aktywność rozpuszczalnych $\mathrm{w}$ wodzie wydzielin liści grochu. Wydzieliny różnych liści wytwarzanych przy węzłach były zbierane poprzez zanurzanie ich w sterylizowanej wodzie destylowanej na różny okres czasu i obserwowano kiełkowanie konidiów grzybów niepatogenicznych dla grochu (Aletrnaria solani, Curvularia lunata, Helminthosporium penniseti i H. echinocloa). Wydzieliny liści w rozmaity sposób inhibitowały kiełkowanie konidiów, a A. solani i C. lunata okazały się wysoce wrażliwe. Kiełkowanie konidiów E. pisi było lepsze na liściach grochu pozbawionych wydzielin. Dwubiegunowe kiełkowanie było najwyższe na II i III liściach węzłowych zanurzonych $\mathrm{w}$ destylowanej wodzie na 18 godzin, podczas gdy po 24 godzinach było najwyższe na I liściach węzłowych. Podobnie, kiełkowanie konidiów E. pisi było obserwowane na różnych liściach węzłowych grochu różnego wieku. Było jasne, że na młodych liściach kiełkowanie nie występowało, a na tych samych węzłowych liściach konidia kiełkowały wraz ze wzrostem ich wieku. Nie obserwowano kiełkowania na liściach węzłowych młodszych niż 20-dniowe. Ponadto wykazano, że 30-dniowe liście były wysoce wrażliwe, gdyż dwubiegunowe kiełkowanie konidiów E. pisi było maksymalne i nie zmieniało się wraz z ich starzeniem się. 